\title{
Organisational tensions and the relationship to CSR in the football sector
}

\author{
Pedersen, Esben Rahbek Gjerdrum; Rosati, Francesco
}

Published in:

European Sport Management Quarterly

Link to article, DOI:

10.1080/16184742.2018.1546754

Publication date:

2019

Document Version

Peer reviewed version

Link back to DTU Orbit

Citation (APA):

Pedersen, E. R. G., \& Rosati, F. (2019). Organisational tensions and the relationship to CSR in the football sector. European Sport Management Quarterly, 19(1), 38-57. https://doi.org/10.1080/16184742.2018.1546754

\section{General rights}

Copyright and moral rights for the publications made accessible in the public portal are retained by the authors and/or other copyright owners and it is a condition of accessing publications that users recognise and abide by the legal requirements associated with these rights.

- Users may download and print one copy of any publication from the public portal for the purpose of private study or research.

- You may not further distribute the material or use it for any profit-making activity or commercial gain

- You may freely distribute the URL identifying the publication in the public portal 


\title{
Organisational tensions and the relationship to CSR in the football sector
}

\author{
Esben Rahbek Gjerdrum Pedersen (ergp.msc@cbs.dk) \\ Department of Management, Society and Communication, Copenhagen Business School, \\ Frederiksberg, Denmark
}

\section{Francesco Rosati (rro@dtu.dk) ${ }^{1}$}

Department of Management Engineering, Technical University of Denmark, Kgs. Lyngby, Denmark

\footnotetext{
${ }^{1}$ Corresponding Author: Francesco Rosati (frro@dtu.dk), Department of Management Engineering, Technical University of Denmark, Centrifugevej, Building 372, room 207, DK-2800 Lyngby, Tel: +45 45256021.
} 


\begin{abstract}
Research question: The objective of this paper is to examine how Danish football ('soccer') clubs perceive organisational tensions, and to explore the relationship between the level of tensions and the level of CSR activity.
\end{abstract}

Research Methods: The analysis is based on survey responses from 226 Danish football clubs organised in the Danish Football Association (DFA).

Results and Findings: It is concluded that clubs primarily face tensions linked to football/nonfootball activities and elite/grassroot discussions. Moreover, the results demonstrate a significant, positive relationship between the level of organisational tensions and the clubs' engagement in social and environmental activities.

Implications: The paper moves beyond isolated studies of individual tensions by analysing how organisation members perceive the multitude of oppositional demands permeating organisations. Moreover, the quantitative analysis advances our knowledge about the complex relationship between organisational tensions and CSR.

Key words: Tensions, Corporate Social Responsibility (CSR), Sustainability, Sport, Football/Soccer. 


\section{Introduction}

Recently, corporate social responsibility (CSR) has come to the fore as a means to manage, organise and control the non-sport dimensions of football. The emergence of CSR on the football agenda is partly due to the commercialisation of the sport, which implies that the clubs - like any other commercial business - increasingly encounter CSR demands from stakeholders (Anagnostopoulos and Shilbury, 2013). Moreover, it has been argued that football is a social institution that can be used by public and private actors to further their own social and environmental policies (Breitbarth, Hovemann and Walzel 2011). Overall, CSR in sport is dominated by an instrumental perspective, where social and environmental initiatives are introduced as a means to achieve organisational ends, even though the actual impacts from CSR remains subject to debate (Walzel, Robertson and Anagnostopoulos, 2018).

In the general CSR literature, however, scholars are also increasingly emphasising the role of tensions and related phenomena such as paradoxes, contradictions, and dilemmas (see e.g. Allen, Marshall and Easterby-Smith, 2015; Hahn, Pinkse, Preuss and Figge 2015). Tensions are defined here broadly as the simultaneous existence of apparently oppositional demands. A tension-based perspective can be said to break with the large body of literature on the 'business case for CSR', which focuses on the alignment between economic, social and environmental objectives (Carroll and Shabana, 2010; Hahn et al., 2015). From a tensions-based perspective, oppositional demands are an inherent part of organising; thus, CSR also means working with and through paradoxes, contradictions and trade-offs (Epstein, Buhovac and Yuthas, 2015; Smith and Lewis, 2011).

While the existing research has provided many useful insights about individual tensions, little is known about the broader tension landscapes within organisations and their relationships to CSR. The current focus on individual tensions comes with advantages in terms of clarity and testing but has 
limitations in terms of understanding the multiplicity of tensions and their interdependent relationships (Schad, Lewis, Raisch and Smith, 2016). Looking more closely at the literature on tensions and CSR, there is also a tendency to view CSR as the source of tension (e.g. between social mission and profit maximisation) rather than a reflection of broader and more general tensions existing within an organisation. CSR (or lack hereof) may be related to more fundamental tensions found within an organisation (e.g. between short-term/long-term and collaboration/control).

The aim of this paper is to take a closer look at how organisational tensions manifested in football clubs, and to explore the relationship between the multiplicity of oppositional demands and the level of CSR activity. This paper thereby contributes to the rapidly growing body of research on organisational tensions by examining the plethora of oppositional demands within organisations and their internal relationships. Moreover, this paper supplements the current discussions of organisational tensions and CSR by testing the relationship between the overall 'tension landscape' within an organisation and the uptake of CSR. Empirically, the analysis draws on survey data from 226 Danish football ('soccer') clubs ranging from very small, community-based clubs to larger organisations with paid staff and players.

\section{The Emerging CSR Discourse in the Football Sector}

In the last decades, CSR has moved from the margins to the mainstream of management research and practice. While the exact meaning of the concept is still being debated, CSR is, in general, about the integration of social and environmental concerns in the management and operations of an organisation (Marrewijk and Werre, 2003). On a more abstract level, Mark S. Schwartz and Archie B. Carroll (2007) propose that broader business and society agendas rest on the joint ideas of value, balance, and accountability. Based on this framework, CSR means an emphasis on long-term societal value over short-term organisational goals. Moreover, societal value is best created through a process of 
balancing multiple stakeholder interests. Lastly, accountability implies that CSR rests on ideas of transparency and honesty in the disclosure of activities and their impacts.

Organisations in different contexts are likely to demonstrate different levels of economic, social and environmental performance (Griffin and Mahon, 1997). Over the years, a large number of studies have linked CSR to a variety of internal and external factors including organisational capabilities, stakeholder pressures and broader institutional forces (Aragón-Correa, Hurtado-Torres, Sharma and Garcia-Morales, 2008; Matten and Moon, 2008; Sharma and Henriques, 2005). Moreover, industryspecific factors are likely to have an impact on corporate social performance (Aguinis and Glavis, 2012). The defining characteristics of sport and the potential influence on the scale and scope of CSR activities have also been subject to debate in the academic literature (Babiak and Wolfe, 2009; Breitbarth, Walzel, Anagnostopoulos and Eekenen, 2015; Smith and Westerbeek, 2007).

As with in the corporate world, sport organisations at all levels are now launching CSR initiatives, which are supported by organisational tools, rankings, reporting, codes of ethics, and partnerships (Walters and Tacon, 2010; Castro-Martinez and Jackson, 2015). However, where conventional CSR in the private sector grew out of a criticism of business conduct, the situation is markedly different in sport, which is often associated with a number of positive characteristics and potentials. Over the years, sport has been linked to peace, community building, education, inclusion, health promotion and social capital (Giulianotti, 2015; Jenkins and James, 2015). The win-win discourse is also found in the literature on CSR in sport where social and environmental investments are expected to bring about benefits for the club as well as for its stakeholders (Breitbarth et al., 2011; Smith and Westerbeek, 2007).

However, a number of caveats have to be mentioned when it comes to CSR in sport. First, clubs are not automatically responsible and woven into their local communities (Walters and Tacon, 2011). 
Second, while sport is widely associated with positive societal impacts, it has also been linked to less desirable phenomena including hooliganism, violence, racism, corruption, doping, lack of transparency, fraud and match-fixing (Anagnostopoulos and Shilbury, 2013; Blumrodt et al., 2012). Third, little is known about the resources and capabilities required for clubs to address CSR independently and in collaboration with private companies and other partners (Smith and Westerbeek, 2007). Fourth, the evidence behind the claims about the wider societal benefits from CSR in sport is often limited and anecdotic in nature (Babiak and Wolfe, 2009; Walters and Tacon, 2010). Therefore, there has recently been calls for a more critical approach to research on CSR and sport (Breitbarth et al., 2015). Overall, more knowledge is needed on how sport clubs practice CSR as well as the underlying drivers, mediating factors, outputs and outcomes.

\section{On Organisational Tensions}

Tensions emerge when organisations experience the simultaneous existence of apparently oppositional demands. In recent years, management and organisation literature has experienced a growing interest in tensions and related concepts such as paradoxes, contradictions, and dilemmas (for a discussion of the terms see e.g. Smith and Lewis, 2011). Researchers have documented the emergence of multiple opposing forces within organisations that relate to different domains including mission (purpose vs. profit), innovation (exploitation vs. exploration), stakeholder management (inclusion vs. exclusion), and time horizon (short-term vs. long-term) (Birkinshaw, Foss and Lindenberg, 2014; Raisch, Birkinshaw, Probst and Tushman, 2009; Slawinski and Bansal, 2015). Moreover, scholars have analysed the manifestations of tensions in a variety of organisations ranging from private enterprises (Smith, Binns and Tushman, 2010) to hybrid organisations (Jay, 2013), nonprofits (Solebello, Tschirhart and Leiter, 2016) and various collaborative arrangements (Sharma and 
Bansal, 2017). Lastly, the identification of organisational tensions has inspired researchers to identify various typologies of responses (Jarzabkowski and Lê, 2016; Schad et al., 2016).

The existence of tensions has also been addressed in the academic literature on football and sport in general, where clubs must often cope with multiple, and not necessarily consistent, stakeholder demands. For instance, one of the recurrent tensions highlighted in the literature concerns the growing commercialisation of sport. Sport is no longer just a hobby or grassroot activity; it is also a billion dollar business with some clubs operating as multinational corporations (Anagnostopoulos and Shilbury, 2013; Breitbarth and Harris, 2008). Therefore, some clubs experience a tension between being social institutions embedded in the local community and commercial companies operating a business (Ballegoyen, 2003; Jenkins and James, 2015; Smith and Stewart, 2010). Related to commercialisation is the transition of sport from amateurism toward professionalisation (Ferkins, Shilbury and McDonald, 2005). With professionalisation comes pressure for formalisation, structure and control, which may be challenging to combine with amateur ideals and volunteerism (DFA, 2013). For instance, Hayhurst and Frisby (2010) argue that there is a long history of tensions between high performance sport and mass participation sport, where the former's focus on 'sport development' does not always align with the latter’s 'sport for development’. Other examples of tensions mentioned in the literature include 1) long-term vs. short-term, 2) members vs. customers and 3) collective vs. individual (Castro-Martinez and Jackson, 2015; Hayhurst and Frisby, 2010; Laub, 2012; Kirkegaard, Fester and Gottlieb, 2014).

Overall, it can be assumed from the literature that organisations are rife with tensions (Jarzabkowski and Lê, 2016; Hoffman, 2018. However, while scholars seem to agree that tensions are to be found in all types of organisations and persist over time, less has been done to explore which types of tensions are most prominent and where they are most likely to be found. Rather, existing research tends to give primacy to studies of individual tensions without considering the broader tension 
landscape within organisations. The dominant focus on individual tensions makes it complicated to make conclusions about the relative position of tensions within an organisation and their interdependencies. An example might be discussions about purpose vs. profit linked to questions of temporality (short-term vs. long-term). In essence, we know very little about the multiplicity of tensions within an organisation and how - individually and together - they shape strategic decisions and day-to-day operations.

\section{The Fuzzy Relationship between Organisational Tensions on CSR Practices}

Recently, a number of scholars have drawn attention to the inherent tensions of CSR work (see e.g. Allen et al., 2015; Hahn et al., 2015). The emerging literature on tensions in CSR breaks with the predominant, instrumental view of CSR, which highlight the potential synergies between CSR, strategy, and profit (Carroll and Shabana, 2010; Porter and Kramer, 2011). However, instrumental views of CSR have been met with criticisms for omitting issues without obvious win-win potentials failing to address the ‘tough’ questions (Crane, Palazzo, Spence and Matten, 2014). Therefore, discussions of fit, alignment and integration are increasingly replaced with references to tensions, paradoxes, and dilemmas. Ultimately, CSR practice is very much about coping with tensions as it: “(...) requires managers to simultaneously address widely diverging but interconnected concerns for the natural environment, social welfare, and economic welfare (...)” (Hahn et al., 2014, p. 463).

The existing literature tends to treat CSR as the source of tensions rather than as a symptom of more general characteristics of an organisation. However, observed tensions may not be unique to CSR. For instance, tensions linked to temporality (e.g. short payback requirements for new investments) will also apply to other types of initiatives and functional areas (Pedersen, Rosati, Lauesen and Farsang, 2017; Slawinski and Bansal, 2015). However, the tendency to view CSR as the source of tension makes it somehow difficult to find conceptual and empirical research on the likely correlation 
between organisational tensions and CSR. The problem is further accentuated by the fact that the overall consequences of organisational tensions remain debated. For instance, Schad et al. (2016) show how tensions can potentially inspire multiple negative (chaos, collapse, conflict, etc.) as well as positive consequences (creativity, innovation, learning, etc.). Likewise, Smith and Lewis (2011) argue that paradoxical tensions can give rise to vicious as well as virtuous cycles within the organisation. Therefore, it is difficult to assess if, when and how tensions are likely to inspire negative or positive impacts.

Rather than viewing CSR as the source of tension, this study considers CSR as associated with the overall tension landscape within an organisation. While it remains an empirical question as to how the overall tension landscape is correlated with the organisational commitment to CSR, it is reasonable to assume that the two constructs are correlated. At least, there seems to be consensus in the literature that tensions can influence organisational outcomes, although their nature remains debated (Schad et al., 2016). On the one hand, it seems reasonable to assume that organisations struggling with tensions linked to resource constraints (human, financial, technical) will focus on core operations while giving less priority to new, social and environmental activities. Here, a negative relation between tensions and CSR could be expected as oppositional demands lower the overall engagement in CSR. Such an argument is in line with the 'slack resources' hypothesis, which expects high-performing organisations to demonstrate higher levels of CSR (Bansal, 2003; Waddock and Graves, 1997). On the other hand, CSR has also been reported to be largely about responding to pressures from customers, regulators, non-governmental organisations, and so on (Aguinis and Glavis, 2012; Pedersen and Gwozdz, 2014). Here, it is possible to envision a positive relationship between tensions and CSR as new stakeholder demands may challenge existing organisational prioritisations and mind-sets and inspire the introduction of social and environmental initiatives. 


\section{Method and Dataset}

The research project originally began in 2013 with informal conversations between the lead researcher and the Danish Football Association (DFA) about the possibilities of mapping non-football activities among the clubs organised under DFA (community work, social inclusion, etc.). In Denmark, with less than six million citizens, more than $40 \%$ of the youth play football and the biggest football association, Danish Football Association (DFA), organise more than 100,000 volunteers and 300,000 members (Kirkegaard et al., 2014). In 2014, the conversations led to a pilot study of five football clubs within the Copenhagen area (not included in this paper). The interviews provided a snapshot of how the clubs addressed non-football issues and the results were subsequently communicated to DFA in an internal report. The pilot study also provided input on the variety of tensions experienced by football practitioners more generally, which informed the research design of this study.

This paper is based on the findings from a 2016 online survey among representatives from Danish football clubs. The survey method adopted in this paper supplements existing research on CSR in sport, which has historically been dominated by qualitative approaches (Walzel et al., 2018). The online survey was sent to 885 football clubs with 100+ members organised in DFA. The 100-member threshold was set in agreement with DFA and made to ensure that the survey only included clubs with a minimum of organisation. The survey was carried out in the local language (Danish) and included open as well as closed questions regarding the club’s engagement in football as well as non-football activities. The DFA administered the survey as the respondents were selected from the DFA member database.

229 football clubs responded to the survey (Response rate=25.9\%). Three football clubs were excluded from the sample due to a high amount of either "do not know" answers or because of missing 
answers to the questions relevant to this study. As a result, the study sample was reduced to 226 football clubs. Among these, the majority of the respondents $(183,81.3 \%)$ were chairmen of the clubs. In terms of size, the majority of respondents represent football clubs with a small number of paid staff, as $43.8 \%$ of them have no paid employees, and $81.4 \%$ have less than five paid employees. However, the surveyed football clubs generally rely on a considerable number of volunteers, as $43.4 \%$ of them have 50 or more volunteers, and $73.9 \%$ of them have 25 or more volunteers. A profile of the respondents is included in Table 1.

\begin{tabular}{lr}
\hline Region & Number of respondents (\%) \\
\hline Jutland & $109(48.2 \%)$ \\
Zealand & $61(27.0 \%)$ \\
Fyn & $26(11.5 \%)$ \\
Copenhagen & $20(8.8 \%)$ \\
Lolland-Falster & $5(2.2 \%)$ \\
Bornholm & $4(1.8 \%)$ \\
n/a & $1(0.4 \%)$ \\
\hline Number of volunteers & \\
\hline $0-24$ volunteers & $57(25.2 \%)$ \\
$25-49$ volunteers & $69(30.5 \%)$ \\
$50-99$ volunteers & $52(23.0 \%)$ \\
$>=100$ volunteers & $46(20.4 \%)$ \\
n/a & $2(0.9 \%)$ \\
\hline Total revenues & \\
\hline $0-250.000$ DKK & $51(22.6 \%)$ \\
$250.001-500.000$ DKK & $38(16.8 \%)$ \\
$500.001-1.000 .000$ DKK & $54(23.9 \%)$ \\
$1.000 .001-2.000 .000$ DKK & $32(14.2 \%)$ \\
$>2.000 .000$ DKK & $30(13.3 \%)$ \\
n/a & $21(9.3 \%)$ \\
\hline
\end{tabular}

Table 1: Characteristics of Football Clubs participating in the Survey.

\section{Measurement of variables}

No consensus exists in the academic literature on the measurement of organisational tensions and CSR. Therefore, the scales used for measuring tensions and CSR have been developed by the researchers based on readings of the existing academic literature and in dialogue with the DFA. The precise formulation of the survey questions can be found in a supplementary file. 
To measure the organisational tension landscape, readings of CSR and football research and the broader organisation literature led to the formulation of 17 generic tensions (Anagnostopoulos and Shilbury, 2013; Ballegoyen, 2003; Breitbarth and Harris, 2008; Ferkins et al., 2005; Hayhurst and Frisby, 2010; Jenkins and James, 2015; Kirkegaard et al., 2014; Laub, 2012; Smith and Stewart, 2010). Respondents were asked to give a characterisation of the club based on each of the 17 tensions. The exact phrasing of the survey question was: "How much do you discuss the following themes in the club? (1=Never discussed, 5=Very often discussed)." The Cronbach Alpha for scores on organisational tensions was $91.3 \%$. The questions were subsequently subject to principal component analysis (PCA) (Nardo et al., 2005). The PCA was rotated using the varimax rotation technique to allow for an interpretation of the principal components.

In addition, an open-ended question was formulated where respondents were asked to give a concrete example of an issue discussed within the club. The precise phrasing of the open question was (our translation): "Can you give one concrete example of an issue related to the operations and development of the club that have sparked internal debate? What was the result (if any)?” The intention with the open question was to improve the interpretation of the findings and identify new issues not covered by the survey question with fixed alternatives. The data from the open-ended question was divided into dominant themes/categories through qualitative coding in SPSS. The process of coding was repeated until the data could be grouped into a limited number of dominant themes. A few respondents mentioned several tensions, which implied that the responses were coded in more than one category. The analysis also included coding of the responses to tensions indicated by the respondents. One or more examples from 138 survey respondents could be coded for the analysis. All responses to the open question were in the local language. All quotations used in this paper have been translated by the authors. 
Respondents were asked if their clubs addressed CSR issues. The precise phrasing of the question was: "Does your club work with societal responsibility (integration, environment, equal opportunities, etc.)?” In Danish language, CSR is often translated as “virksomhedens samfundsansvar”, which literally means “the company’s societal responsibility”. Since the study concerns football clubs, the reference to companies was excluded. Respondents from clubs not involved in CSR work were asked for the main reason(s) for their clubs' lack of engagement in these activities. Respondents in clubs working with CSR were asked to indicate the CSR commitment on 20 CSR dimensions, which were identified based on dialogue with DFA, CSR rankings (www.responsiball.org), and the existing literature on CSR and football (see e.g. Jenkins and James, 2015; Sheth and Babiek, 2010; Walker and Kent, 2009; Walker and Parent, 2010). The precise formulation of the question was: "What is covered by your club's societal responsibility? (1=No engagement, 5=Significant engagement).” The Cronbach Alpha for scores on CSR was 79.5\%.

\section{Analysis and Findings}

\section{Outlining the Tension Landscape among Danish Football Clubs}

While it is true that organisations are rife with tensions, the results from the survey indicate that some tensions are more common than others in the football sector. More specifically, the mean scores in Table 2 indicate that concerns over football/non-football activities and a club’s elite/grassroot status remain the most common points of tension, whereas issues relating to dependence/independence and collaboration/competition are rarely discussed in the clubs. A closer analysis of the findings (not shown in Table 2) also suggests that very large football clubs (clubs with more than 100 volunteers) experience higher levels of tension. Moreover, when looking closer at the results from the open questions, discussions about football/non-football activities often seem to be rooted in limited 
volunteer resources. When it comes to tensions linked to the elite/grassroot status of a club there is also a financial dimension as the cost of focusing on elite (typically senior) teams often must be covered by non-elite activities at the junior level. Overall, the results indicate that the most prominent tensions are linked to core operations (football) rather than the general management and organisation of the club.

\begin{tabular}{|c|c|c|c|c|c|}
\hline Item & Mean & $\begin{array}{c}\text { Component 1: } \\
\text { Membership and } \\
\text { independence }\end{array}$ & $\begin{array}{l}\text { Component 2: } \\
\text { Results }\end{array}$ & $\begin{array}{c}\text { Component 3: } \\
\text { Activities and } \\
\text { plans }\end{array}$ & $\begin{array}{l}\text { Component 4: } \\
\text { Community }\end{array}$ \\
\hline Focus on grassroots vs. Focus on elite & 3.37 & -0.04 & 0.61 & -0.07 & -0.09 \\
\hline $\begin{array}{l}\text { Development of football (results) vs. Development through } \\
\text { football (members) }\end{array}$ & 3.25 & -0.06 & 0.51 & 0.04 & 0.14 \\
\hline $\begin{array}{l}\text { Concern for the individual member (e.g. talents) vs. Concern } \\
\text { for the entire team/club }\end{array}$ & 3.16 & 0.02 & 0.36 & 0.10 & 0.19 \\
\hline Football as game/hobby vs. Football as business/work & 2.67 & 0.35 & 0.13 & -0.27 & 0.19 \\
\hline Football as community vs. Football as sport & 3.24 & 0.12 & 0.06 & -0.03 & 0.60 \\
\hline Top-down steering vs. bottom-up steering & 2.59 & 0.27 & 0.00 & 0.11 & 0.19 \\
\hline Everyday club practices vs. long-term development of the club & 3.31 & -0.02 & -0.03 & 0.59 & -0.09 \\
\hline Short-term results vs. Long-term results & 2.93 & 0.08 & -0.03 & 0.46 & -0.02 \\
\hline Members as volunteers vs. Members as customers & 3.04 & 0.22 & -0.12 & 0.30 & -0.01 \\
\hline $\begin{array}{l}\text { Activities on the field (training, matches, tournaments) vs. } \\
\text { activities outside the field (social activities, travelling etc.) }\end{array}$ & 3.38 & -0.16 & 0.11 & 0.43 & 0.20 \\
\hline Room for differences vs. Limitations for acceptable behaviour & 2.95 & 0.10 & 0.05 & 0.19 & 0.32 \\
\hline $\begin{array}{l}\text { Collaboration between the members vs. Competition between } \\
\text { the members }\end{array}$ & 2.35 & 0.41 & -0.06 & -0.04 & 0.14 \\
\hline $\begin{array}{l}\text { Independence of external interests vs. Dependence of external } \\
\text { interests }\end{array}$ & 2.27 & 0.49 & -0.13 & -0.04 & -0.01 \\
\hline Non-paid labour vs. Paid labour & 2.77 & 0.30 & 0.00 & 0.11 & -0.33 \\
\hline $\begin{array}{l}\text { Talent development of own players vs. Recruitment of talents } \\
\text { from outside }\end{array}$ & 2.52 & 0.18 & 0.35 & 0.04 & -0.45 \\
\hline Flexibility vs. Control & 2.62 & 0.27 & 0.19 & 0.03 & -0.11 \\
\hline $\begin{array}{l}\text { Focus on society (people, profit, and planet) vs. Focus on the } \\
\text { (financial) bottom line }\end{array}$ & 2.96 & 0.30 & 0.04 & 0.07 & -0.09 \\
\hline
\end{tabular}

${ }^{a}$ Loadings stronger than \pm 0.40 are in bold type

Table 2: Results of Tensions: Principal Components Analysis. 
The principal component analysis provides further details of the principle components of the 17 tensions (Table 2). The Kaisere-Meyere-Olkin (KMO) measure was used to assess the sampling adequacy and was found to be 0.88 , well above a recommended cut-off threshold of 0.50 (Field, 2009). In particular, four components emerged with large positive eigenvalues $(6.77,1.37,1.25$ and 1.14), accounting for $62.0 \%$ of the total variance. Table 2 shows the component matrix post varimax rotation. Based on the component matrix, Component 1 (membership and independence) captured tensions regarding collaboration/competition between members and independence/dependence from external interests. Component 2 (results) included tensions concerning grassroot/elite status and the orientation towards results/members. Component 3 (activities and plans) included tensions emerging from prioritisations (activities on the field/activities off the field) and planning (everyday club practices/long-term development of the club, short-term/long-term results). Component 4 (community) included tensions regarding football seen as a community/sport and talent development of own players vs. recruitment of talent from the outside.

In the open survey question, respondents provided examples of issues that sparked internal debate within the club. The results from the coding are summarised in Table 3 with a few illustrative examples. In line with the findings above, the results indicate that some tensions are more prevalent than others. More specifically, respondents often report tensions related to club activities and the internal hierarchy of teams. For instance, one of the survey respondents highlights the elite/non-elite question between teams: “The club is non-elite (according to official statutes). When an individual team develops to become more than non-elite, then the discussion about non-elite/elite gives rise to a lot of challenges. It is a difficult balance.” Moreover, respondents highlight some practical challenges (e.g. the collection of membership fees and the maintenance of physical facilities) that cannot directly be considered an organisational tension. However, as will be discussed later, some practical challenges can be seen as representations of more fundamental and deeper-held tensions within the 
club (e.g. What are the core vs. non-core activities in the club? Should football be available to

everyone or only to those able to pay full membership fees?).

\begin{tabular}{|c|c|}
\hline Category: & $\begin{array}{c}\text { Illustrative examples: } \\
\end{array}$ \\
\hline $\begin{array}{l}\text { Team issues (junior/senior, } \\
\text { elite/non-elite etc.) } \\
(\mathrm{N}=38)\end{array}$ & $\begin{array}{l}\text { "Membership fees mainly come from junior football whereas the majority of costs } \\
\text { are linked to older, more elite teams. No end results, as it is still a debated topic. We } \\
\text { introduce differentiated membership fees for A- and B-teams and an elite fee and } \\
\text { hope that it will minimise some of the discussions and dissatisfaction." } \\
\text { "Junior/Senior. Where should the money be spent? The result was a compromise, } \\
\text { which caused a lot of dissatisfaction in both camps". }\end{array}$ \\
\hline $\begin{array}{l}\text { Volunteer issues (recruitment, } \\
\text { retention etc.) } \\
(\mathrm{N}=20)\end{array}$ & $\begin{array}{l}\text { "It is difficult to find time to innovate, when it is the same people who are responsible } \\
\text { for operations. Operations is the highest priority in the club and it is difficult to find } \\
\text { time for anything else". } \\
\text { "Which activities should run? Every week, the club house is used for bingo which is } \\
\text { also a piece of social work. Should we continue when it takes up many volunteer } \\
\text { resources? For now, we continue as long as there are many elderly people in the } \\
\text { club". }\end{array}$ \\
\hline $\begin{array}{l}\text { Membership fees } \\
(\mathrm{N}=20)\end{array}$ & $\begin{array}{l}\text { "The structure of membership fees within the club. Who should pay what? This is an } \\
\text { ongoing debate and will continue to be so in many years ahead." } \\
\text { "We had difficulties in getting people to pay their membership fees on time. During } \\
\text { the last two years, it has occupied } 75 \text { percent of the board's work. However, now we } \\
\text { have been able to turn this around." }\end{array}$ \\
\hline $\begin{array}{l}\text { Partners (other sports, clubs, } \\
\text { sponsors, etc.) } \\
(\mathrm{N}=14)\end{array}$ & $\begin{array}{l}\text { "Is in a diverse sport club that is jointly liable. We wish to split up the finances, which } \\
\text { will probably result in dissolution of the current club structure." } \\
\text { "We once had a debate about a sponsor, who gave us quite a lot of money, but also } \\
\text { interfered with training and prioritizations. The club "won" and the sponsor left. It } \\
\text { was a good solution although we lost a lot of money." }\end{array}$ \\
\hline $\begin{array}{l}\text { Financial constraints } \\
(\mathrm{N}=14)\end{array}$ & $\begin{array}{l}\text { "It requires a lot of work to make ends meet. We are two clubs who collaborate on } \\
\text { running a football department and it can create some problems due to different club } \\
\text { cultures" } \\
\text { "There are not money to acquire enough equipment for training. The result is that } \\
\text { nobody wants to share, because they are afraid that their equipment will never be } \\
\text { returned". }\end{array}$ \\
\hline $\begin{array}{l}\text { Player/parent attitudes and } \\
\text { behaviour } \\
(\mathrm{N}=11)\end{array}$ & $\begin{array}{l}\text { "Lack of parent support. We educated two mentors for recruitment to "parent teams" } \\
\text { and contact to the parents." } \\
\text { "We lose a lot of players (children) as a result of other interests and lack of parent } \\
\text { support to the local club. It is too easy to move the children because we request more } \\
\text { involvement from the parents (...). However, we do not have the solution for how to } \\
\text { retain the children (read: parents) and how to motivate the parents help more with } \\
\text { training instead of just complaining about the skills of the volunteers." }\end{array}$ \\
\hline $\begin{array}{l}\text { Paid/non-paid support } \\
(\mathrm{N}=9)\end{array}$ & $\begin{array}{l}\text { "Where is the boundary between voluntarism vs. paid staff? How to make life as a } \\
\text { volunteer easier? No result yet. It is a discussion that we have to work on and } \\
\text { specify." } \\
\text { "Recruitment of external, paid trainer, including discussions of the type and amount } \\
\text { of tasks the trainer should be able to influence (.,.)." }\end{array}$ \\
\hline $\begin{array}{l}\text { Facilities (lightning, fields, } \\
\text { change rooms etc.) } \\
(\mathrm{N}=8)\end{array}$ & $\begin{array}{l}\text { "Dialogue with the municipality about football fields and financial support. Still } \\
\text { working on the problem" }\end{array}$ \\
\hline Other issues & $\begin{array}{l}\text { "Past vs. present. There are a lot of feelings in a small club" } \\
\text { "Who gets the revenues from sponsors? Team or club?" }\end{array}$ \\
\hline
\end{tabular}




\begin{tabular}{|l|l|}
\hline$(\mathrm{N}=22)$ & $\begin{array}{l}\text { "Decentralisation of responsibility vs. central steering of the club. The result was a } \\
\text { broad description of the tasks, which could be handled at the decentral level." }\end{array}$ \\
\hline
\end{tabular}

Table 3: Tensions addressed by survey respondents in open question.

When looking closer at the responses to tension in the open question, there was almost an equal split between respondents who indicated a solution $(n=67)$ and those who did not $(n=71)$. With regards to the former, the following is an example of an issue indicting a solution: "There was too much focus on the "elite" status of the club. As a result, the vision of the club was forgotten and the club almost died. A new board of directors and the introduction of quality management have put the club back on track. Now it is a club with room for everyone." With regards to the latter, a number of respondents made statements such as: "a fight we still have”, "we do not have the solution”, "no clarification”, “no result”, “we have not reached a result”, “we are still working on it”, “ongoing,” "solution not found yet," "still talking about it" and "it is still being debated”. The results indicate the persistent nature of tensions, which are seen as normal and part of being a member of a club.

\section{The Relationship between Organisational Tensions and CSR}

115 respondents (50.4\%) indicate that the club works with societal responsibility/CSR. Among the clubs working with CSR, fair play is by far the most common topic area (Table 4). This is perhaps not surprising, as it relates directly to core football activities and has also been promoted at the regional, national and international level. Moreover, the Danish football sector has also been influenced by the migrant crisis. Therefore, a number of football clubs have opened their doors for refugees and migrants. Other common themes involve transparency, equal opportunities, and antidiscrimination. Overall, the participants of the survey deemed environmental issues less relevant. A likely explanation is that the physical football infrastructure is typically owned, managed and operated by local municipalities. Therefore, it seems only logical that clubs primarily focus on activities where they have the most influence and impact. When comparing CSR with the size of the 
clubs (not shown in Table 4), very large football clubs demonstrate higher levels of average CSR activity.

\begin{tabular}{lcccccc}
\hline Item & N & Average & Rank & Median & Mode & St Dev \\
\hline CSR 1 - Donations & 110 & 1.75 & 16 & 1 & 1 & 1.02 \\
CSR 2 - Healthy food & 111 & 2.22 & 12 & 2 & 1 & 1.12 \\
CSR 3 - Activities towards obese children and young people & 111 & 1.77 & 15 & 2 & 1 & 0.89 \\
CSR 4 - Integration of refugees and migrants & 115 & 3.20 & 2 & 3 & 3 & 1.19 \\
CSR 5 - Supplier relations & 112 & 1.61 & 19 & 1 & 1 & 0.83 \\
CSR 6 - Fighting discrimination and racism & 113 & 2.96 & 5 & 3 & 3 & 1.26 \\
CSR 7 - Better working conditions for employees and volunteers & 113 & 2.70 & 6 & 3 & 3 & 1.22 \\
CSR 8 - Initiatives against abuse & 112 & 2.17 & 13 & 2 & 1 & 1.20 \\
CSR 9 - Fighting match fixing and corruption & 113 & 2.31 & 10 & 2 & 1 & 1.38 \\
CSR 10 - Football activities towards non-active citizens & 114 & 2.24 & 11 & 2 & 1 & 1.12 \\
CSR 11 - Fair play on and outside the field & 115 & 3.92 & 1 & 4 & 4 & 0.91 \\
CSR 12 - Equal opportunities & 112 & 3.04 & 4 & 3 & 3 & 1.32 \\
CSR 13 - Education of children and young people & 115 & 2.60 & 7 & 2 & 2 & 1.28 \\
CSR 14 - Promotion of transparency in club finances and economy & 114 & 3.10 & 3 & 3 & 3 & 1.16 \\
CSR 15 - Activities directed towards disabled and/or sick people & 111 & 1.65 & 18 & 1 & 1 & 0.98 \\
CSR 16 - Initiatives to reduce transport costs or membership fees & 112 & 2.52 & 8 & 3 & 3 & 1.19 \\
CSR 17 - Initiatives to improve resource consumption & 111 & 1.79 & 14 & 1 & 1 & 1.11 \\
CSR 18 - Volunteer work to social activities & 113 & 2.43 & 9 & 2 & 2 & 1.19 \\
CSR 19 - Football projects in developing countries & 111 & 1.48 & 20 & 1 & 1 & 0.95 \\
CSR 20 - Initiatives towards unemployed & 110 & 1.68 & 17 & 1 & 1 & 1.19 \\
CSR (Average) & 115 & 2.38 & - & 2.32 & 1.95 & 0.61 \\
\hline
\end{tabular}

Table 4: Descriptive statistics of CSR items.

The correlation between average tensions and average engagement in CSR activities (Pearson correlation $=0.545)$ is positive and statistically significantly relevant $(p$-value $<0.01)$. Therefore, the results indicate that football clubs with higher average levels of organisational tensions show higher average levels of engagement in CSR activities. The regression analysis presented in Table 5 shows that organisational tensions in football clubs are positively associated with overall engagement in CSR activities, even when controlling for the clubs' sizes $(b=0.547$, OR $=1.728){ }^{2}$

\footnotetext{
${ }^{2}$ In this regression analysis, we considered a subset of 115 observations, for which we found no missing values in the answers to the questions on tensions and CSR.
} 


\begin{tabular}{|c|c|c|c|c|c|c|c|c|c|c|}
\hline & $\boldsymbol{b}$ & OR & $\begin{array}{l}\text { Standard } \\
\text { error }\end{array}$ & $\mathbf{T}$ & $\mathbf{p}>|\mathbf{t}|$ & $\operatorname{bStd}_{X}$ & $\mathbf{R}^{2}$ & $\operatorname{Adj}^{2}$ & $F(1,113)$ & $\begin{array}{l}\text { Root } \\
\text { MSE }\end{array}$ \\
\hline $\begin{array}{l}\text { Tensions } \\
\text { Constant }\end{array}$ & $\begin{array}{l}0.547^{* * *} \\
0.657^{* *}\end{array}$ & $\begin{array}{c}1.728 \\
-\end{array}$ & $\begin{array}{l}0.083 \\
0.254\end{array}$ & $\begin{array}{l}6.58 \\
2.59\end{array}$ & $\begin{array}{l}0.000 \\
0.011\end{array}$ & 0.528 & 0.306 & 0.293 & $24.68^{* * *}$ & 0.514 \\
\hline
\end{tabular}

Dependent variable: Average CSR engagement; method of estimation: regression; $b=$ raw coefficient; OR=Odds Ratio $\left(e^{b}\right) ; t=t$-score for test of $b=0 ; p>|t|=p$-value for $t$-test; $b S t d x=X$ standardized coefficient. $R^{2}=R$-squared; $A d j R^{2}=$ Adjusted $R$-Squared; Root MSE = root-mean-square error. The results are controlled for clubs' size (measured as number of volunteers). Multicollinearity was absent, with variance inflation factors lower than 1.04. Statistical significance: ${ }^{*} p$-value $<0.10,{ }^{* *} p$-value $<0.05,{ }^{* * *} p$-value $<0.01$. Number of observations after listwise exclusion $=115$.

Table 5: Regression results predicting overall engagement in CSR.

Further analyses of the individual items of tensions and CSR (Table 6) show that TEN16 (flexibility vs. control), TEN17 (focus on society (people, profit, planet) vs. focus on the (financial) bottom line) and TEN15 (talent development of own players vs. recruitment of talent from outside) show the highest correlations with an average level of CSR (Pearson correlation $=0.486,0.451$ and 0.447 respectively). On the other hand, TEN3 (concern for the individual member vs. concern for the entire team/club) and TEN10 (activities on the field vs. activities off the field) present the lowest and least significant correlations with CSR (Pearson correlation $=0.156$ and 0.175 respectively). Discussions regarding the prioritisation (sustainability vs. finance) and formalisation (flexibility vs. control) thus seem to be catalysts for introducing social and environmental initiatives in the club.

Focusing on individual CSR items, we observe that CSR9 (fighting match-fixing and corruption), CSR5 (supplier relations - e.g. requirements towards environment and labour conditions), CSR7 (better working conditions for employees and volunteers) and CSR14 (the promotion of transparency in club finances and economy) show the highest correlations with individual types of tensions as well as with the total average level of tensions (Pearson correlation $=0.430,0.365,0.352$ and 0.352 respectively). CSR16 (initiatives to reduce transport costs or membership fees) CSR4 (the integration of refugees and migrants) and CSR2 (healthy food) on the other hand present the lowest and least significant correlations with respect to tensions.

Finally, analyses between individual CSR items and individual tensions show that CSR9 and TEN15 present the highest correlation (Pearson correlation $=0.444$ ), followed by CSR5 and TEN16 (Pearson 
correlation $=0.416)$, CSR9 and TEN16 (Pearson correlation $=0.407)$ and CSR14 and TEN16 (Pearson correlation $=0.398)$. Some CSR issues thus seem to be sensitive to the organisational tensions (and vice versa), whereas others exist independent of internal discussions of oppositional demands. Given the positive correlation between organisational tensions and CSR, one may speculate if the adoption of CSR issues is linked to their ability to address multiple tension domains with an organisation.

To further investigate the sensitiveness of individual CSR issues to organisational tensions, we performed a multivariate regression analysis considering the average level of tensions as the independent variable, the CSR activities as the dependent variables, and the size of the football clubs as the control variable (Table 7). Overall, the results from the analysis show that average tensions are generally associated with a higher engagement in CSR activities. A closer analysis confirms the result of the correlation analysis (Table 6) by indicating that one CSR activity out of twenty is not significantly associated with average organisational tensions (CSR16) ( $p$-value $=0.422$ ). The nineteen other CSR areas all show a positive significant association with tensions. In particular, football clubs with a high average level of organisational tensions are more likely to fight match fixing and corruption (CSR9) $(b=0.963$; OR = 2.620; $p$-value $<0.01)$, offer good working conditions to employees and volunteers (CSR7) $(b=0.726$; OR $=2.067 ; p$-value $<0.01)$, promote transparency in club finances and economy (CSR14) $(b=0.665$; OR $=1.944 ; p$-value $<0.01)$, be engaged in initiatives against abuse (CSR8) (e.g. smoking, alcohol, gambling addiction) $(b=0.664$; OR = 1.943; $p$-value $<0.01)$, and fight discrimination and racism (CSR6) $(b=0.656$; OR $=1.927 ; p$-value $<0.01)$. 


\begin{tabular}{|c|c|c|c|c|c|c|c|c|c|c|c|c|c|c|c|c|c|c|c|c|c|}
\hline & CSR1 & CSR2 & CSR3 & CSR4 & CSR5 & CSR6 & CSR7 & CSR8 & CSR9 & CSR10 & CSR11 & CSR12 & CSR13 & $\begin{array}{l}\text { CSR14 } \\
\end{array}$ & CSR15 & CSR16 & $\begin{array}{l}\text { CSR17 } \\
\end{array}$ & CSR18 & CSR19 & CSR20 & CSRavg \\
\hline TEN1 & 0.079 & 0.062 & 0.101 & 0.154 & 0.066 & $0.244^{* * *}$ & 0.116 & 0.114 & $0.181^{*}$ & 0.149 & 0.020 & $0.222^{* *}$ & -0.054 & $0.225^{* *}$ & 0.122 & 0.119 & 0.065 & 0.066 & 0.137 & 0.020 & $0.225^{* *}$ \\
\hline TEN2 & $0.234^{* * *}$ & $0.182^{*}$ & 0.154 & 0.071 & 0.090 & $0.160^{*}$ & 0.126 & $0.174^{*}$ & $0.297^{*+*}$ & $0.277^{+* n+x}$ & -0.015 & $0.173^{*}$ & 0.153 & $0.191^{* *}$ & 0.148 & $0.176^{*}$ & 0.136 & 0.139 & $0.200^{* *}$ & $0.195^{* *}$ & $0.334^{*+* *+}$ \\
\hline TEN3 & 0.064 & -0.006 & 0.034 & 0.103 & 0.026 & 0.047 & 0.097 & 0.047 & $0.161^{*}$ & $0.250^{*+* *+}$ & $0.195^{* *}$ & 0.121 & 0.014 & -0.068 & 0.072 & -0.100 & 0.006 & -0.039 & 0.121 & 0.104 & $0.156^{*}$ \\
\hline TEN4 & $0.194^{* *}$ & -0.041 & 0.086 & 0.136 & $0.279^{*+*}$ & $0.170^{*}$ & 0.142 & $0.176^{*}$ & $0.274^{* * * *}$ & 0.134 & $0.220^{* *}$ & $0.165^{*}$ & $0.172^{*}$ & $0.240^{* * *}$ & $0.181^{*}$ & 0.061 & $0.159^{*}$ & $0.159^{*}$ & 0.149 & $0.277^{*+*}$ & $0.339^{*+* *}$ \\
\hline TEN5 & 0.017 & -0.105 & 0.069 & 0.106 & 0.110 & $0.211^{* *}$ & $0.270^{* * *}$ & 0.072 & 0.043 & $0.267^{+\cdots *}$ & 0.146 & -0.138 & $0.166^{*}$ & $0.156^{*}$ & 0.008 & 0.080 & 0.033 & 0.099 & -0.051 & -0.033 & $0.185^{* *}$ \\
\hline TEN6 & $0.225^{* *}$ & 0.034 & 0.033 & $0.222^{2 * *}$ & $0.314^{* * * *}$ & $0.166^{*}$ & 0.127 & $0.161^{*}$ & $0.255^{* * *}$ & $0.242^{* * *}$ & 0.116 & 0.089 & $0.159^{*}$ & $0.162^{*}$ & $0.303^{+* * *}$ & 0.016 & 0.140 & 0.081 & $0.259^{*+* *}$ & $0.198^{* *}$ & $0.331^{*+* x}$ \\
\hline TEN7 & $0.214^{* *}$ & $0.289^{* * *}$ & 0.122 & -0.013 & 0.100 & 0.049 & $0.256^{* * *}$ & $0.164^{*}$ & $0.215^{* *}$ & 0.153 & 0.128 & 0.130 & $0.184^{* *}$ & $0.208^{* *}$ & 0.108 & -0.104 & 0.030 & 0.107 & 0.127 & $0.165^{*}$ & $0.266^{* * *+}$ \\
\hline TEN8 & 0.073 & 0.151 & 0.040 & 0.036 & $0.165^{*}$ & 0.119 & $0.177^{*}$ & 0.045 & 0.148 & 0.089 & $0.312^{+* *}$ & $0.163^{*}$ & 0.091 & $0.225^{* *}$ & 0.098 & -0.057 & 0.071 & 0.047 & 0.060 & 0.123 & $0.223^{* *}$ \\
\hline TEN9 & $0.165^{*}$ & $0.233^{* *}$ & $0.259^{* * *}$ & -0.004 & $0.227^{* *}$ & 0.036 & $0.208^{* *}$ & $0.204^{* *}$ & $0.294^{* * *}$ & $0.280^{*+* *}$ & $0.243^{* *}$ & 0.088 & $0.314^{* * *}$ & 0.147 & $0.235^{* *}$ & 0.058 & 0.071 & $0.257^{* * *}$ & 0.122 & $0.187^{*}$ & $0.357^{+* * *}$ \\
\hline TEN10 & -0.075 & 0.112 & 0.021 & 0.078 & 0.072 & 0.141 & $0.226^{* *}$ & $0.170^{*}$ & $0.167^{*}$ & $0.176^{*}$ & $0.301^{* * *}$ & 0.078 & 0.120 & 0.004 & -0.117 & 0.031 & -0.008 & 0.052 & -0.095 & 0.039 & $0.175^{*}$ \\
\hline TEN11 & $0.173^{*}$ & 0.054 & 0.143 & 0.127 & $0.212^{* *}$ & $0.287^{* * * *}$ & $0.203^{* *}$ & $0.199^{* *}$ & $0.246^{* * * *}$ & $0.189^{* * *}$ & $0.359^{* * *}$ & 0.017 & $0.202^{* *}$ & 0.146 & 0.118 & 0.094 & 0.153 & 0.129 & $0.160^{*}$ & 0.110 & $0.324^{* * * *}$ \\
\hline TEN12 & $0.189^{* *}$ & 0.088 & 0.131 & 0.097 & $0.354^{* * * *}$ & 0.103 & 0.127 & $0.288^{* * *}$ & $0.255^{* * * *}$ & $0.163^{*}$ & $0.293^{* * *}$ & $0.248^{* * *}$ & $0.228^{* *}$ & $0.175^{*}$ & $0.182^{*}$ & 0.053 & $0.158^{*}$ & 0.155 & $0.303^{* * x}$ & $0.168^{*}$ & $0.371^{* * * *}$ \\
\hline TEN13 & $0.206^{* *}$ & 0.076 & 0.126 & 0.130 & $0.303^{* * *}$ & 0.079 & $0.217^{* *}$ & $0.290^{* * *}$ & $0.297^{* * *}$ & $0.188^{* *}$ & 0.116 & $0.173^{*}$ & $0.313^{* * * *}$ & $0.181^{*}$ & $0.353^{* * * x}$ & 0.020 & 0.149 & $0.185^{*}$ & $0.278^{* * *}$ & $0.233^{* *}$ & $0.394^{*+* x}$ \\
\hline TEN14 & 0.072 & 0.154 & $0.168^{*}$ & 0.092 & $0.185^{*}$ & $0.172^{*}$ & $0.207^{* *}$ & 0.122 & $0.256^{* * *}$ & 0.112 & 0.051 & $0.232^{* *}$ & $0.175^{*}$ & $0.260^{*+*+*}$ & $0.318^{* * * *}$ & 0.020 & $0.237^{* *}$ & 0.096 & 0.046 & $0.159^{*}$ & $0.305^{* * *}$ \\
\hline TEN15 & $0.185^{*}$ & $0.239^{* *}$ & $0.267^{* * *}$ & $0.164^{*}$ & $0.281^{* * *}$ & $0.234^{* *}$ & $0.253^{* * * *}$ & $0.276^{* * *}$ & $0.444^{* * * *}$ & 0.020 & $0.253^{* * *}$ & $0.315^{* * *}$ & 0.105 & $0.382^{+* * *}$ & $0.164^{*}$ & 0.091 & $0.249^{n+*}$ & 0.125 & 0.135 & $0.311^{* * * *}$ & $0.447^{* * *}$ \\
\hline TEN16 & $0.340^{* * * *}$ & $0.236^{* *}$ & $0.329^{* * *}$ & 0.145 & $0.416^{* * * *}$ & $0.277^{* * *}$ & $0.336^{* * *}$ & $0.351^{* * *}$ & $0.407^{* * * *}$ & 0.158 & $0.303^{* * *}$ & $0.182^{*}$ & $0.202^{* *}$ & $0.398^{* * *}$ & $0.286^{* * *}$ & 0.088 & $0.218^{* *}$ & 0.129 & 0.156 & $0.230^{* *}$ & $0.486^{* * * *}$ \\
\hline TEN17 & $0.201^{* *}$ & 0.063 & $0.198^{* *}$ & $0.206^{* *}$ & $0.317^{*+*}$ & $0.285^{* * * *}$ & $0.326^{* * * *}$ & $0.300^{* * *}$ & $0.298^{* * * *}$ & $0.187^{* *}$ & $0.324^{*-*}$ & 0.137 & $0.229^{* *}$ & $0.358^{+* *+}$ & $0.229^{* *}$ & 0.084 & 0.092 & $0.256^{* * *}$ & $0.216^{* *}$ & 0.125 & $0.451^{*+*+*}$ \\
\hline TENavg & $0.263^{* \cdots *}$ & $0.191^{* *}$ & $0.237^{* *}$ & $0.185^{* *}$ & $0.365^{* * * *}$ & $0.288^{* * * *}$ & $0.352^{* * * *}$ & $0.323^{* * *}$ & $0.430^{* * * *}$ & $0.301^{* * * *}$ & $0.322^{\cdots * *}$ & $0.247^{* * * *}$ & $0.280^{* * * *}$ & $0.352^{* * * *}$ & $0.296^{* * * *}$ & 0.078 & $0.208^{* *}$ & $0.207^{* *}$ & $0.240^{* *}$ & $0.271^{* * *}$ & $0.545^{* * *+}$ \\
\hline
\end{tabular}

Statistical significance: ${ }^{*} p$-value $<0.10,{ }^{* *}$-value $<0.05,{ }^{* * *} p$-value $<0.01$

Table 6: Correlation between tensions and CSR items. 


\begin{tabular}{|c|c|c|c|c|c|c|c|c|c|c|c|}
\hline Dependent variable & $\begin{array}{c}\text { Independent } \\
\text { variable }\end{array}$ & $\boldsymbol{b}$ & OR & $\begin{array}{c}\text { Standard } \\
\text { error }\end{array}$ & $\mathbf{T}$ & $\mathbf{p}>|\mathbf{t}|$ & bStd $_{X}$ & $R^{2}$ & $\operatorname{Adj} R^{2}$ & $\boldsymbol{F}$ & $\begin{array}{l}\text { Root } \\
\text { MSE }\end{array}$ \\
\hline CSR1 - Donations (aid & Tensions & $0.485^{* * *}$ & 1.624 & 0.170 & 2.87 & 0.005 & 0.272 & & & & \\
\hline $\begin{array}{l}\text { organisations, elderly } \\
\text { care, leisure clubs etc.) }\end{array}$ & Constant & 0.310 & - & 0.518 & 0.60 & 0.551 & & 0.071 & 0.054 & $4.10^{* *}$ & 0.996 \\
\hline $\begin{array}{l}\text { CSR2 - Healthy food (e.g. } \\
\text { in the canteen) }\end{array}$ & $\begin{array}{l}\text { Tensions } \\
\text { Constant } \\
\end{array}$ & $\begin{array}{l}0.352^{*} \\
1.100^{*} \\
\end{array}$ & $\begin{array}{c}1.422 \\
- \\
\end{array}$ & $\begin{array}{l}0.187 \\
0.564\end{array}$ & $\begin{array}{l}1.88 \\
1.95 \\
\end{array}$ & $\begin{array}{l}0.062 \\
0.054\end{array}$ & 0.181 & 0.039 & 0.021 & 2.19 & 1.103 \\
\hline $\begin{array}{l}\text { CSR3 - Activities towards } \\
\text { obese children and young } \\
\text { people }\end{array}$ & $\begin{array}{l}\text { Tensions } \\
\text { Constant }\end{array}$ & $\begin{array}{l}0.345^{* *} \\
0.681\end{array}$ & $\begin{array}{c}1.412 \\
-\end{array}$ & $\begin{array}{l}0.145 \\
0.439\end{array}$ & $\begin{array}{l}2.38 \\
1.55\end{array}$ & $\begin{array}{l}0.019 \\
0.123\end{array}$ & 0.227 & 0.058 & 0.040 & $3.32^{* *}$ & 0.876 \\
\hline $\begin{array}{l}\text { CSR4 - Integration of } \\
\text { refugees and migrants }\end{array}$ & $\begin{array}{l}\text { Tensions } \\
\text { Constant }\end{array}$ & $\begin{array}{c}0.365^{*} \\
2.065^{* * *}\end{array}$ & $\begin{array}{c}1.441 \\
-\end{array}$ & $\begin{array}{l}0.190 \\
0.581\end{array}$ & $\begin{array}{l}1.92 \\
3.55\end{array}$ & $\begin{array}{l}0.058 \\
0.001\end{array}$ & 0.181 & 0.034 & 0.017 & 2.00 & 1.176 \\
\hline $\begin{array}{l}\text { CSR5 - Supplier relations } \\
\text { (e.g. requirements to } \\
\text { environment and labour } \\
\text { conditions) }\end{array}$ & $\begin{array}{l}\text { Tensions } \\
\text { Constant }\end{array}$ & $\begin{array}{l}0.530^{* * *} \\
0.015\end{array}$ & $\begin{array}{c}1.699 \\
-\end{array}$ & $\begin{array}{l}0.130 \\
0.396\end{array}$ & $\begin{array}{l}4.07 \\
0.04\end{array}$ & $\begin{array}{l}0.000 \\
0.970\end{array}$ & 0.369 & 0.134 & 0.118 & $8.41^{* * *}$ & 0.780 \\
\hline $\begin{array}{l}\text { CSR6 - Fighting } \\
\text { discrimination and racism }\end{array}$ & $\begin{array}{l}\text { Tensions } \\
\text { Constant } \\
\end{array}$ & $\begin{array}{l}0.656^{* * *} \\
1.042^{*} \\
\end{array}$ & $\begin{array}{c}1.927 \\
- \\
\end{array}$ & $\begin{array}{l}0.201 \\
0.615 \\
\end{array}$ & $\begin{array}{l}3.27 \\
1.69 \\
\end{array}$ & $\begin{array}{l}0.001 \\
0.093 \\
\end{array}$ & 0.303 & 0.089 & 0.072 & $5.35^{* * *}$ & 1.214 \\
\hline $\begin{array}{l}\text { CSR7 - Better working } \\
\text { conditions for employees } \\
\text { and volunteers }\end{array}$ & $\begin{array}{l}\text { Tensions } \\
\text { Constant }\end{array}$ & $\begin{array}{c}0.726^{* * *} \\
0.446\end{array}$ & $\begin{array}{c}2.067 \\
-\end{array}$ & $\begin{array}{l}0.191 \\
0.582\end{array}$ & $\begin{array}{l}3.80 \\
0.77\end{array}$ & $\begin{array}{l}0.000 \\
0.445\end{array}$ & 0.345 & 0.125 & 0.109 & $7.87^{* * *}$ & 1.148 \\
\hline $\begin{array}{l}\text { CSR8 - Initiatives against } \\
\text { abuse (smoking, alcohol, } \\
\text { gambling, ludomani) }\end{array}$ & $\begin{array}{l}\text { Tensions } \\
\text { Constant }\end{array}$ & $\begin{array}{c}0.664^{* * *} \\
0.135\end{array}$ & $\begin{array}{c}1.943 \\
-\end{array}$ & $\begin{array}{l}0.191 \\
0.581\end{array}$ & $\begin{array}{l}3.48 \\
0.23\end{array}$ & $\begin{array}{l}0.001 \\
0.817\end{array}$ & 0.321 & 0.105 & 0.088 & $6.38^{* * *}$ & 1.146 \\
\hline $\begin{array}{l}\text { CSR9 - Fighting match } \\
\text { fixing and corruption }\end{array}$ & $\begin{array}{l}\text { Tensions } \\
\text { Constant }\end{array}$ & $\begin{array}{l}0.963^{* * *} \\
-0.748\end{array}$ & $\begin{array}{c}2.620 \\
-\end{array}$ & $\begin{array}{l}0.204 \\
0.622\end{array}$ & $\begin{array}{c}4.72 \\
- \\
1.20 \\
\end{array}$ & $\begin{array}{l}0.000 \\
0.232\end{array}$ & 0.412 & 0.193 & 0.179 & $13.17^{* * *}$ & 1.247 \\
\hline $\begin{array}{l}\text { CSR10 - Football } \\
\text { activities towards non- } \\
\text { active citizens }\end{array}$ & $\begin{array}{l}\text { Tensions } \\
\text { Constant }\end{array}$ & $\begin{array}{l}0.541^{* * *} \\
0.502\end{array}$ & $\begin{array}{c}1.718 \\
-\end{array}$ & $\begin{array}{l}0.173 \\
0.531\end{array}$ & $\begin{array}{l}3.12 \\
0.94\end{array}$ & $\begin{array}{l}0.002 \\
0.347\end{array}$ & 0.287 & 0.096 & 0.080 & $5.89^{* * *}$ & 1.070 \\
\hline $\begin{array}{l}\text { CSR11 - Fair play on and } \\
\text { outside the field }\end{array}$ & $\begin{array}{l}\text { Tensions } \\
\text { Constant } \\
\end{array}$ & $\begin{array}{l}0.541^{* * *} \\
2.397^{* * *}\end{array}$ & $\begin{array}{c}1.718 \\
- \\
\end{array}$ & $\begin{array}{l}0.139 \\
0.424 \\
\end{array}$ & $\begin{array}{l}3.91 \\
5.66 \\
\end{array}$ & $\begin{array}{l}0.000 \\
0.000 \\
\end{array}$ & 0.351 & 0.127 & 0.112 & $8.16^{* * *}$ & 0.857 \\
\hline $\begin{array}{l}\text { CSR12 - Equal } \\
\text { opportunities (gender, } \\
\text { ethnicity, age etc.) }\end{array}$ & $\begin{array}{l}\text { Tensions } \\
\text { Constant }\end{array}$ & $\begin{array}{l}0.520^{* *} \\
1.352^{* *}\end{array}$ & $\begin{array}{c}1.682 \\
-\end{array}$ & $\begin{array}{l}0.214 \\
0.652\end{array}$ & $\begin{array}{l}2.43 \\
2.07\end{array}$ & $\begin{array}{l}0.017 \\
0.041\end{array}$ & 0.229 & 0.068 & 0.051 & $3.98^{* *}$ & 1.284 \\
\hline $\begin{array}{l}\text { CSR13 - Education of } \\
\text { children and young } \\
\text { people (e.g. collaboration } \\
\text { with schools) }\end{array}$ & $\begin{array}{l}\text { Tensions } \\
\text { Constant }\end{array}$ & $\begin{array}{c}0.563^{* * *} \\
0.758\end{array}$ & $\begin{array}{c}1.756 \\
-\end{array}$ & $\begin{array}{l}0.199 \\
0.607\end{array}$ & $\begin{array}{l}2.83 \\
1.25\end{array}$ & $\begin{array}{l}0.005 \\
0.215\end{array}$ & 0.260 & 0.089 & 0.073 & $5.47^{* * *}$ & 1.229 \\
\hline $\begin{array}{l}\text { CSR14 - Promotion of } \\
\text { transparency in club } \\
\text { finances and economy }\end{array}$ & $\begin{array}{l}\text { Tensions } \\
\text { Constant }\end{array}$ & $\begin{array}{l}0.665^{* * *} \\
0.994^{*}\end{array}$ & $\begin{array}{c}1.944 \\
-\end{array}$ & $\begin{array}{l}0.177 \\
0.540\end{array}$ & $\begin{array}{l}3.76 \\
1.84\end{array}$ & $\begin{array}{l}0.000 \\
0.068\end{array}$ & 0.340 & 0.128 & 0.113 & $8.18^{* * *}$ & 1.092 \\
\hline $\begin{array}{l}\text { CSR15 - Activities } \\
\text { directed towards disabled } \\
\text { and/or sick people (e.g. } \\
\text { diabetes) }\end{array}$ & $\begin{array}{l}\text { Tensions } \\
\text { Constant }\end{array}$ & $\begin{array}{c}0.424^{* * *} \\
0.148\end{array}$ & $\begin{array}{c}1.528 \\
-\end{array}$ & $\begin{array}{l}0.153 \\
0.464\end{array}$ & $\begin{array}{l}2.77 \\
0.32\end{array}$ & $\begin{array}{l}0.007 \\
0.750\end{array}$ & 0.251 & 0.143 & 0.127 & $9.03^{* * *}$ & 0.914 \\
\hline $\begin{array}{l}\text { CSR16 - Initiatives to } \\
\text { reduce transport costs or } \\
\text { membership fees }\end{array}$ & $\begin{array}{l}\text { Tensions } \\
\text { Constant }\end{array}$ & $\begin{array}{c}0.157 \\
2.047^{* * *}\end{array}$ & $\begin{array}{c}1.170 \\
-\end{array}$ & $\begin{array}{l}0.195 \\
0.606\end{array}$ & $\begin{array}{l}0.81 \\
3.38\end{array}$ & $\begin{array}{l}0.422 \\
0.001\end{array}$ & 0.077 & 0.008 & -0.011 & 0.42 & 1.196 \\
\hline $\begin{array}{l}\text { CSR17 - Initiatives to } \\
\text { improve resource } \\
\text { consumption (e.g. water } \\
\text { and electricity) }\end{array}$ & $\begin{array}{l}\text { Tensions } \\
\text { Constant }\end{array}$ & $\begin{array}{c}0.397^{* *} \\
0.598\end{array}$ & $\begin{array}{c}1.487 \\
-\end{array}$ & $\begin{array}{l}0.181 \\
0.560\end{array}$ & $\begin{array}{l}2.20 \\
1.07\end{array}$ & $\begin{array}{l}0.030 \\
0.288\end{array}$ & 0.207 & 0.048 & 0.030 & $2.68^{*}$ & 1.099 \\
\hline $\begin{array}{l}\text { CSR18 - Volunteer work } \\
\text { to social activities } \\
\text { (national collections, } \\
\text { charity runs etc.) }\end{array}$ & $\begin{array}{l}\text { Tensions } \\
\text { Constant }\end{array}$ & $\begin{array}{l}0.422^{* *} \\
1.173^{* *}\end{array}$ & $\begin{array}{c}1.525 \\
-\end{array}$ & $\begin{array}{l}0.190 \\
0.589\end{array}$ & $\begin{array}{l}2.22 \\
1.99\end{array}$ & $\begin{array}{l}0.028 \\
0.049\end{array}$ & 0.207 & 0.056 & 0.039 & $3.24^{* *}$ & 1.168 \\
\hline $\begin{array}{l}\text { CSR19 - Football projects } \\
\text { in developing countries }\end{array}$ & $\begin{array}{l}\text { Tensions } \\
\text { Constant } \\
\end{array}$ & $\begin{array}{c}0.325^{* *} \\
0.303\end{array}$ & $\begin{array}{c}1.384 \\
- \\
\end{array}$ & $\begin{array}{l}0.151 \\
0.461 \\
\end{array}$ & $\begin{array}{l}2.15 \\
0.66 \\
\end{array}$ & $\begin{array}{l}0.034 \\
0.513 \\
\end{array}$ & 0.199 & 0.102 & 0.086 & $6.15^{* * *}$ & 0.910 \\
\hline $\begin{array}{l}\text { CSR20 - Initiatives } \\
\text { towards unemployed }\end{array}$ & $\begin{array}{l}\text { Tensions } \\
\text { Constant }\end{array}$ & $\begin{array}{c}0.446^{* *} \\
0.004\end{array}$ & $\begin{array}{c}1.562 \\
-\end{array}$ & $\begin{array}{l}0.183 \\
0.557\end{array}$ & $\begin{array}{l}2.44 \\
0.01\end{array}$ & $\begin{array}{l}0.016 \\
0.994\end{array}$ & 0.219 & 0.162 & 0.146 & $10.32^{* * *}$ & 1.098 \\
\hline
\end{tabular}

Dependent variable: business case; method of estimation: regression; $b=$ raw coefficient; OR $=$ Odds Ratio ( $\left.e^{b}\right)$; $t=t$-score for test of $b=0 ; p>|t|=p$-value for $t$-test $; b S t d x=X$ standardized coefficient; $R^{2}=R$-squared; AdjR $R^{2}$ Adjusted $R$-Squared; Root $M S E=$ rootmean-square error. The results were controlled for clubs' size (measured as number of volunteers). Multicollinearity was absent, with variance inflation factors always lower than 1.05. Statistical significance: *p-value $<0.10, * * p-v a l u e<0.05$, ***p-value $<0.01$. Number of observations ranging from 110 to 115, depending on the CSR item.

Table 7: Multivariate Regression results predicting engagement on different CSR activities as a function of average level of tension 


\section{Discussion of Findings}

Tensions can be seen as an inescapable part of organizing, which exist at all times and across all levels, and can give rise to a variety of responses ranging from denial and opposition to confrontation and transcendence (Jarzabkowski and Lê, 2016). Over the years, scholars from various disciplines have therefore examined the manifestations, origins and consequences of tensions and related concepts such as paradoxes, contradictions, dualities, dichotomies and dilemmas (Jarzabkowski and Fenton, 2006; Smith and Lewis, 2011). Tensions are also well known within the sport sector that forms the empirical basis of this paper (see e.g. Castro-Martinez and Jackson, 2015).

The results from the analysis demonstrates how organisations experience multiple, interrelated tensions. For instance, tensions linked to teams and results seem to be distinct from tensions associated with the management and organisation of clubs. Overall, the findings highlight the need for supplementing existing analyses of individual tensions with a broader understanding of multiple, intertwined tensions. However, more work is needed before researchers are able to move beyond atomised studies of individual tensions and explore the relationships between oppositional demands and organisational outcomes.

The most prominent tensions identified concern the grassroots vs. elite statuses of clubs and the clubs' broader goals for the development of football vs. development through football. The results resonate with previous studies that have emphasised the tensions that exist between performance sport and participation sport (Hayhurst and Frisby, 2010). In other ways, however, the results of this study diverge from the literature, which up until now have largely focused on the clash between communal and commercial objectives (Boyd and Stahley, 2008; Hamil and Morrow, 2011; Jenkins and James, 2015). For instance, Ballegoyen (2003) has highlighted the dual nature of football clubs (non-profit and for-profit), which are often stuck between being social institutions and commercial enterprises. 
In some countries, this tension has inspired clubs to establish separate organisations dedicated to CSR and community programmes (Anagnostopoulos et al., 2014). The divergence between the study results and the existing literature can likely be attributed to the research design and the profiles of respondents. This study mainly covers amateur clubs, whereas existing research has largely focused on professional clubs, which are more likely to be exposed to tensions between communitas ('good') and corporatas ('gain') (Boyd and Stahley, 2008).

The results also indicate that tensions are a fundamental part of the organisational fabric, which organisation members to a large extent simply have to live with. There is almost a 50/50 split between survey respondents indicating a solution to a challenge and those who do not. Here, the findings seem to highlight an apparent paradox in the existing literature on tensions. On the one hand, there seems to be consensus about the persistent nature of tensions and their resistance to resolution (Schad et al., 2016; van der Byl and Slawinski, 2015). On the other hand, the literature remains 'biased towards action' by highlighting various types of response strategies and tactics for addressing tensions. Over the years, researchers have outlined a broad palette of actions available to strategists trying to cope with tensions (Jarzabkowski and Lê 2016; Lewis and Smith, 2014; van der Byl and Slawinski, 2015). However, the evidence from this study indicates that a common approach to tensions is to not act at all. Therefore, action, as well as non-action, should be included in the repertoire of responses to organisational tensions.

The findings also indicate that some tensions can be traced back to fundamental resource constraints - whether human (lack of volunteers), financial (lack of income) or physical (lack of facilities). For instance, one of the survey respondents link the classic tension between exploitation/exploration to the lack of volunteer resources: "Currently, we are having a discussion about how many new things we can start compared to how we can just keep the engine running. A lack of volunteers implies that things we start put pressure on the board, which, in turn, impacts daily operations.” The quotation 
indicates a need to discuss the link between fundamental tensions rooted in oppositional demands and tensions caused by the everyday prioritisation of scarce resources. Some tensions propelled to paradoxes in the literature may simply reflect the practical act of making a formal/informal hierarchy of concerns with due respect to available resources (Harlez and Malagueño, 2016).

The paper examines the relationship between organisational tensions and the level of CSR activity. CSR literature is rich in discussions about the internal and external factors that shape and are shaped by CSR including management commitment, stakeholder demands and institutional pressures (Bebbington, 2009; Jackson \& Apostolakou, 2010; Menguc et al., 2010). These discussions are also found in sport management literature where the determinants of CSR have been subject to debate (Babiak and Wolfe, 2009; Trendafilova et al., 2013). However, so far, little research exists on the relationship between the tensions perceived by an organisation's members and the level of CSR activity within that organisation.

The findings suggest that there is a positive correlation between organisational tensions and a club’s engagement in CSR. Football clubs experiencing higher level of tensions are more likely to engage in various CSR activities. Here, the findings offer a valuable supplement to existing literature, which tend to focus on how CSR gives rise to tensions linked to costs/benefits, short-term/long-term, topdown/bottom-up, and inclusion/exclusion (see e.g. Birkin, Polesie and Lewis, 2009; Slawinski and Bansal, 2015). However, the evidence from this analysis indicates that CSR is linked to more general organisational tensions. While the study cannot make conclusions about causality, the findings seem to resonate with previous studies suggesting that tensions may spur new activity - in this case with CSR (see Schad et al., 2016).

Overall, the results point to a need to further explore how tensions may act as a driver, mediator, and moderator of CSR and other organisational phenomena (Aguinis and Glavis, 2012). For instance, 
future studies may investigate when and how oppositional demands spark action and non-action within organisations. Moreover, there is a need to understand where and how tensions are manifested in organisations. For instance, it may very well be that many clubs experience tensions between sport and non-sport activities, but that these tensions are not felt in the same way across all levels, divisions, functions, teams, and groups. Likewise, there is a need for understanding about how the composition of tensions evolve over time, and further research needs to look closer at the negotiated processes among practitioners responsible for balancing contradictory demands. Finally, there is a need for discussing when tensions are either conducive or destructive for the development of the organisation.

\section{Conclusion}

The objective of this paper was to explore the organisational tensions among Danish football clubs and their relationship to the level of CSR activity. Rather than emphasizing one type of tension, the paper adopts a broader perspective by looking at how multiple, oppositional demands individually and in combination are associated with the commitment to CSR among football clubs. The results from the analysis indicate that football clubs experience multiple, intertwined tensions regarding football/non-football activities, elite/non-elite statuses, professionalism/voluntarism, etc. Moreover, the findings demonstrate that the average level of tensions within the club is positively correlated with CSR. The findings suggest that CSR should not only be seen as a source of tension but is also related to broader oppositional demands permeating the organisation.

The results from the study cannot automatically be generalized. The scales used for measuring organisational tensions and CSR were designed specifically for the sport context. Therefore, the paper only represents a first step in developing a generic scale for measuring organisational tensions. Moreover, the findings are based on survey evidence from a limited number of clubs within a single geographical area (Denmark). For instance, the clubs covered in this study are to a large extent run 
by volunteers. It is likely that larger professional sport clubs will experience different combinations of tensions and CSR. Moreover, it is generally acknowledged that the institutional environment influences organisations and their approach to CSR (Matten and Moon, 2008). For instance, Scandinavian countries are known for high levels of participation (Arnesen et al., 2013), low power distance (Hofstede, 2001), collaborative relationships between employers and employees (Cevea, 2013), and interaction across sectors (state, market and civil society) (Strand and Freeman, 2015). Therefore, the results from the study cannot easily be transferred to other fields, sectors, and geographies.

However, the chosen method also comes with advantages. Football - and sport more generally - is characterised by an enormous variety ranging from large, professional organisations to small, local clubs with only a handful of players (Miragaia, Brito and Ferreira, 2016). The quantitative inquiry of tensions and CSR practices among a broad spectrum of football clubs supplements existing research, which has so far been biased toward large, professional clubs in Europe and conducted mostly in the UK, where CSR is said to be more institutionalised compared to other countries (see e.g. Anagnostopoulos et al, 2014; Walzel et al., 2018). This study provides evidence of CSR among a broad range of football clubs within a geographical context that has rarely been subject to large empirical inquiries in academic sport literature (Walzel et al., 2018).

That being said, the results from the study call for deeper analyses of the dynamic interplay between organisational tensions and CSR in everyday organisational practices and how this relationship evolves over time. While this study has shown an overall relationship between the two phenomena, more work is needed in order to look closer at the everyday practices of perceiving and acting on tensions and CSR. Moreover, there is still a need to provide a stronger basis for analysing if, when and how the combination of tensions within the organisation stimulates creativity and change compared to resistance, inertia, and conflict. All organisations experience multiple tensions, but some 
constellations may serve as a springboard for new CSR innovation whereas others may hamper the management and organisation of CSR. 